\title{
Hepatitis C virus-related lymphoproliferative disorders encompass a broader clinical and morphological spectrum than previously recognized: a clinicopathological study
}

Manuela Mollejo ${ }^{1}$, Javier Menárguez ${ }^{2}$, Pablo Guisado-Vasco ${ }^{3}$, Leyre Bento ${ }^{4}$, Patrocinio Algara ${ }^{5}$, Santiago Montes-Moreno ${ }^{6}$, María S Rodriguez-Pinilla ${ }^{7}$, Miguel A Cruz $^{8}$, Felipe Casado ${ }^{9}$, Carlos Montalbán ${ }^{3}$ and Miguel A Piris ${ }^{6}$

${ }^{1}$ Department of Pathology, Hospital Virgen de la Salud, Toledo, Spain; ${ }^{2}$ Department of Pathology, Hospital Gregorio Marañón, Madrid, Spain; ${ }^{3}$ Department of Internal Medicine, Hospital Ramón y Cajal, Madrid, Spain; ${ }^{4}$ Department of Haematology, Hospital Gregorio Marañon, Madrid, Spain; ${ }^{5}$ Department of Genetics, Hospital Virgen de la Salud, Toledo, Spain; ${ }^{6}$ Department of Pathology, Hospital Universitario Marqués de Valdecilla-IFIMAV, Santander, Spain; ${ }^{7}$ Department of Pathology, Fundación Jiménez Díaz, Madrid, Spain; ${ }^{8}$ Department of Oncology, Hospital Virgen de la Salud, Toledo, Spain and ${ }^{9}$ Department of Haematology, Hospital Virgen de la Salud, Toledo, Spain

\begin{abstract}
We describe a retrospective series of B-cell lymphoproliferative disorders associated with hepatitis C virus infection. In addition to splenic marginal zone lymphoma, follicular lymphoma and diffuse large B-cell lymphoma, all of which showed some specific features, we found two poorly described groups of cases. The first featured disseminated marginal zone lymphoma without splenic marginal zone lymphoma features, defying the current marginal zone lymphoma classification; the other consisted of monoclonal B lymphocytes in the peripheral blood, bone marrow or other tissues, with no clinical or histological evidence of lymphoma, and exhibiting a pattern that requires proper identification in order to avoid the misdiagnosis of the lymphoma. Diagnosis of hepatitis $\mathrm{C}$ virus infection-associated lymphoproliferative disorders requires the integration of clinical, pathological and molecular findings to establish an adequate diagnosis and decide the appropriate therapy to be applied.

Modern Pathology (2014) 27, 281-293; doi:10.1038/modpathol.2013.120; published online 9 August 2013
\end{abstract}

Keywords: HCV infection; lymphoma; monoclonal lymphocytosis; splenic marginal zone lymphoma

The presence of hepatitis C virus (HCV) is associated with a constellation of lymphoproliferative disorders, ranging from benign polyclonal/oligoclonal B-cell expansion to overt malignant lymphoma. It is a multifactorial and multistep process in which many genetic and environmental changes are probably required before a malignant phenotype is fully acquired. ${ }^{1}$ On the one hand, small B-cell clones can be detected in the bone marrow and liver biopsies of HCV-positive patients, and these are occasionally associated with a serum cryoprecipitable IgM Kappa component. $^{1,2}$ On the other hand, a higher

Correspondence: Dr M Mollejo, MD, PhD, Pathology Service, Hospital Virgen de la Salud, Avenida Barber, 30, Toledo 45004, Spain.

E-mail: mmollejov@sescam.jccm.es

Received 15 October 2012; revised 17 April 2013; accepted 18 April 2013; published online 9 August 2013 frequency of lymphoid malignant neoplasms has been described in HCV-infected patients. These are most commonly lymphoplasmacytic lymphomas, marginal zone lymphomas and diffuse large B-cell lymphomas. ${ }^{3}$ The clinical relevance of these disorders is highlighted by the finding that antiviral therapy may lead to the regression of a fraction of these HCV-related lymphomas. ${ }^{4}$

The pattern of association between HCV infection and lymphoproliferative disorders differs throughout the world. For example, a significantly higher risk of non-Hodgkin lymphoma in HCVpositive patients has been noticed in several countries. ${ }^{5-7}$

Although there have been several reports of the clinical characterization of the range of lymphoproliferative disorders associated with HCV infection, detailed morphological information and diagnostic features are still lacking, and as a consequence, 
malignancy is sometimes overdiagnosed. Additionally, little is known about the evolution of these disorders and their response to antiviral therapy.

The aim of this study was to describe the spectrum of morphological, phenotypic and clinical findings in a series of lymphoproliferative disorders in HCV-positive patients.

\section{Materials and methods}

\section{Case Selection}

We searched for B-cell lymphoma or monoclonal B-cell lymphoproliferative lesions, determined by PCR, immunohistochemical analysis and/or flow cytometry, in HCV-positive patients, diagnosed between 2000 and 2010. Samples were obtained from the Pathology Department of the Gregorio Marañón (Madrid) and Virgen de la Salud (Toledo) Hospitals and the Spanish National Cancer Research Centre (CNIO). The diagnosis of HCV infection was confirmed in all the patients by the detection of antiHCV and/or HCV RNA in the serum. We excluded cases with HIV and/or HBV chronic infection and patients who had undergone organ transplantation. The liver biopsies were considered in the diagnosis of liver disease but not included in the morphological, phenotypic and molecular analysis that sought monoclonal B-cell populations. We identified a total of 77 patients with lymphoma and monoclonal B-cell lymphoproliferative disease with HCV infection. From these, 19 were excluded because of HIV coinfection (12 cases), organ transplantation (3 cases), autoimmune disease (1 case), associated T-cell lymphoma (1 case), diagnosis of lymphoma before the diagnosis of HCV infection (1 case) and because the only available material was a splenectomy specimen obtained after chemotherapy treatment (1 case). The total series included 58 patients.

Clinical information was retrieved from medical records, surgical pathology reports and the referring clinicians.

The research protocol was approved by the Institutional Ethics Committee at the Hospital Virgen de la Salud.

\section{Pathological Findings}

The samples analyzed in this series included 54 bone marrow, 15 lymph node, 2 bronchial, 1 pleural, 4 cutaneous, 1 gastric, 1 nasal and 3 liver biopsies and 11 splenectomy specimens. In total, 92 formalin-fixed, paraffin-embedded samples were available for morphological and immunohistochemical examination

Histological diagnoses were reviewed by MAP, JM and MM in accordance with the criteria of the World Health Organization lymphoma classification and the following criteria:
(A) Splenic marginal zone lymphoma:

Splenic histology showing a splenic marginal zone pattern. ${ }^{8,9}$

(B) Marginal zone lymphoma different from splenic marginal zone:

(a) Nodal and/or extranodal tissue showing a marginal zone lymphoma pattern, without evidence of splenic disease; ${ }^{10,11}$

(b) Monoclonal B-cell population in the bone marrow/peripheral blood and organ lesions or lymphadenopathy, as demonstrated by physical examination or imaging techniques.

(C) HCV-associated monoclonal B-cell lymphocytosis:

Monoclonal B-cell expansions (PCR and/or immunohistochemistry and/or flow cytometry) in the bone marrow and/or peripheral blood. Absence of lymphoma infiltration by physical examination or histology. ${ }^{12}$

(D) Tissue-based monoclonal B-cell and plasma cell proliferations of uncertain type:

Monoclonal B-cell populations demonstrated by PCR or light-chain restriction involving lymph node or spleen or extranodal tissue, in the absence of histological evidence of lymphoma infiltration or clinical evidence of disease.

The other diagnoses included in this study (lymphoplasmacytic lymphomas, follicular lymphoma, diffuse large B-cell lymphomas, chronic lymphocytic leukemia, multiple myeloma) were made according to the WHO criteria. ${ }^{13-17}$

For immunohistochemical staining, $4-\mu \mathrm{m}$-thick paraffin-embedded tissue sections were subsequently dewaxed, rehydrated and subjected to antigen retrieval using EnVision FLEX target retrieval solution at $\mathrm{pH} 6$ and heated at $95^{\circ} \mathrm{C}$. Slides were cooled and treated with EnVision FLEX/HRP Technique (Dako), counterstained with hematoxylin and mounted. The primary antibodies used were CD20, CD3, BCL2, BCL6, IgD, ki67, cyclin D1, kappa and lambda (Dako, Glostrup, Denmark), CD10 and p53 (Novocastra, Newcastle, UK).

\section{FISH for BCL2 Gene Rearrangements}

FISH assays were performed on paraffin-embedded samples. Briefly, hybridizations were done overnight at $37^{\circ} \mathrm{C}$ after deparaffinization of $4-\mu \mathrm{m}$-thick sections of tissue, target retrieval by pressurecooking with $1 \mathrm{mM}$ EDTA for $10 \mathrm{~min}$ and pepsin digestion $\left(4 \mathrm{mg} / \mathrm{ml}\right.$ at $37^{\circ} \mathrm{C}$ for $\left.60 \mathrm{~min}\right)$. The probe used was the LSI IGH/BCL2 Dual FUSION Color Probe, Break Apart Rearrangement Probe (Vysis, Downers Grove, IL, USA).

\section{IgH Analysis}

Genomic DNA was extracted from paraffin-embedded tissue with proteinase $\mathrm{K}$ and purified using a QIAGEN kit. The clonal IgVH rearrangements were analyzed by PCR using JH and VH consensus primers 
and BCL2 MBR and JH primers, respectively, from BIOMED-2 concerted action. ${ }^{18}$ PCR amplification products were analyzed by ABI Genescan (ABI 310 PRISM) and agarose, respectively. IgVH gene status was investigated in five cases.

\section{Results}

\section{Patients}

Table 1 summarizes the patients' clinical features. Fifty-eight patients with histological, phenotypic or molecular evidence of lymphoma or monoclonal B-cells were included. The diagnostic classification of these cases is shown in Table 2. Cryoglobulinemia was reported in 10 patients ( 1 splenic marginal zone lymphoma, 5 marginal zone lymphoma, 3 monoclonal B lymphocytosis and 1 tissue-based monoclonal B-cell and plasma cell proliferations of uncertain type).

After a median 43 months of follow-up, 15 patients were dead but only in 2 cases could the cause of death be attributed to lymphoma progression; the rest died of sepsis (6 patients), vasculitis (3 patients), epithelial tumors (1 colorectal carcinoma and 1 urothelial carcinoma case), 5 days after splenectomy (1 patient) or from hepatic failure (1 patient). Eighteen patients received antiviral therapy and 27 received chemotherapy, 11 of these after antiviral therapy. Patients receiving any type of treatment (antiviral therapy and/or chemotherapy) had better overall survival than untreated patients.

We have information about the time between the diagnoses of HCV infection and of lymphoproliferative disorders only from 15 cases. The two conditions were diagnosed simultaneously in three patients, while there was an interval of 4-27 years in the others.

\section{Splenic Marginal Zone Lymphoma Cases}

We included in this group only splenic marginal zone lymphoma cases in which the diagnosis had been confirmed after a review of a splenectomy specimen in order to be sure of the lymphoma diagnosis. This ensured the exclusion of monoclonal lymphocytosis without splenic tissue involvement. We found only seven cases of splenic marginal zone lymphoma diagnosed in splenectomy specimens in our institutions and among the consultation cases with clinical information about HCV status. One of these patients was diagnosed with bone marrow involvement of a monoclonal B-cell lymphocytosis, and the splenic marginal zone lymphoma diagnosis was established only shortly after the review of the pathological findings from the spleen, which had been removed 20 years before.

Clinical findings. Seven patients were included in this group (6 females, 1 male), with a median age of 67 years (range, 52-76 years). Bone marrow was
Table 1 Summary of clinical findings of 58 patients

\begin{tabular}{lc}
\hline $\begin{array}{l}\text { Main clinical findings } \\
\text { Patients }\end{array}$ \\
Gender, M:F & 58 \\
Age, mean (range) & $33: 25$ \\
Splenomegaly (\%) & $63(28-91)$ \\
Bone marrow involvement (\%) & $33 / 56(60)$ \\
Cirrhosis (\%) & $42 / 50(84)$ \\
Hepatocarcinoma & $11 / 56(20)$ \\
Serum monoclonal band & 4 \\
Cryoglobulinemia & 9 (5IgG, 3IgM,1 IgA) \\
Hb (g/dl), mean (range) & 10 \\
Platelets (/ $\mu$ l), mean (range) & $12.6(6.7-17.5)$ \\
Lymphocyte count (/ $\mu$ l), mean (range) & $4614(240-67000)$ \\
Follow-up (months), (range) & $43(1-300)$ \\
Alive/dead/no data & $35 / 15 / 8$
\end{tabular}

involved in all the six six cases examined and peripheral blood involvement was detected in four of them. Abdominal lymph node infiltration was present in one case. Five cases presented with anemia, while thrombopenia was found in four patients. Peripheral blood infiltration was demonstrated by flow cytometry in four patients. The median lymphocyte count was $1730 / \mu \mathrm{l}$ (range, 7502900). Cryoglobulinemia was detected in only one case. Splenectomy was performed for diagnostic and/or therapeutic purposes in all the patients, and chemotherapy was administered in four cases. One patient received antiviral treatment. Five patients were alive after a follow-up of 9, 13, 14, 28 and 288 months, respectively, and two had died, one immediately after the splenectomy.

Pathological features. Molecular and light-chain restriction data are shown in Table 2. All cases were diagnosed from splenectomy specimens. The morphological and phenotypic features of these cases are similar to those of splenic marginal zone lymphoma cases not associated with HCV. ${ }^{9}$ Under low-power examination, all spleens showed micronodular white pulp infiltration with marginal zone differentiation, and the red pulp exhibited dilated sinuses with variable infiltration by small lymphocytes. The phenotype of the neoplastic cells was CD20 +, BCL2 +, BCL6 - , cyclin D1 - , IgD + , with a low proliferation index. By immunohistochemical staining with ki67 and BCL2, the splenectomy specimens frequently featured a mixture of reactive germinal centers, BCL2 - with a high proliferation index and germinal centers partially replaced by BCL2 + tumoral cells with a low proliferation index, reflecting a low level of spleen infiltration. Similarly, CD20 and IgD immunostaining helped to demonstrate the presence of B-cell infiltration in the red pulp (Figure 1). Deletion $7 q$ was found in one case.

The clinical data review of one case diagnosed with B-cell lymphoproliferative disorder in bone marrow specimen in 2006 showed the patient to 
Table 2 Diagnosis in our series of HCV-associated lymphoproliferative disorders

\begin{tabular}{|c|c|c|c|c|c|}
\hline Diagnosis & Cases & $I G H-R$ & Kappa/lambda & PCR-BCL2 & FISH-BCL2 \\
\hline Splenic marginal zone lympoma & 7 & & $4 / 1$ & & \\
\hline Marginal zone lymphoma & 13 & 5 & $4 / 4$ & $0 / 6$ & \\
\hline Monoclonal B lymphocytosis-HCV infection & 11 & 3 & $7 / 2$ & $0 / 3$ & \\
\hline Follicular lymphoma & 8 & 2 & $2 / 0$ & $0 / 2$ & $1 / 1$ \\
\hline Large B-cell lymphoma & 7 & 4 & $2 / 0$ & $0 / 1$ & $0 / 1$ \\
\hline $\begin{array}{l}\text { Lymphoplasmacytic lymphoma/monoclonal gammopathy of } \\
\text { undetermined significance }\end{array}$ & 3 & & $3 / 0$ & $0 / 1$ & \\
\hline Multiple myeloma & 2 & 1 & $1 / 1$ & $0 / 2$ & \\
\hline $\begin{array}{l}\text { Tissue-based monoclonal B-cell and plasma cell proliferations of } \\
\text { uncertain type }\end{array}$ & 3 & 3 & $3 / 0$ & & $0 / 1$ \\
\hline $\begin{array}{l}\text { Others ( } 2 \text { chronic lymphocytic leukemia, } 1 \text { B-cell lymphoma } \\
\text { not otherwise specified, } 1 \text { Burkitt lymphoma) }\end{array}$ & 4 & & $2 / 0$ & & \\
\hline Total & 58 & 18 & $28 / 8$ & $0 / 15$ & $1 / 3$ \\
\hline
\end{tabular}

Abbreviations: FISH-BCL2, Bcl2 rearrangement by FISH; HCV, hepatitis C virus; IGH-R, monoclonal rearrangement of IGH; PCR-BCL2, Bcl2 rearrangement by PCR; SMZL, splenic marginal zone lympoma.

have had a splenectomy 20 years before. The reevaluation of the spleen revealed morphological features typical of splenic marginal zone lymphoma.

Bone marrow biopsy showed infiltration by small lymphocytes in all the cases available. These were interstitial in six cases, with intertrabecular and intrasinusoidal nodules in four and two cases, respectively. Flow cytometry indicated that all three out of the three cases were CD5 - and three out of the four cases expressed kappa.

\section{Marginal Zone Lymphoma-NOS}

This group included patients with nodal or extranodal involvement by marginal zone lymphoma, demonstrated by tissue biopsy with the help of immunohistochemistry, flow cytometry and PCR studies. In addition to nodal marginal zone lymphoma and extranodal marginal zone lymphoma, MALT-type cases, disseminated marginal zone lymphoma cases were included here, some of them with splenomegaly but showing greater than expected visceral or lymph node infiltration.

Clinical findings. The clinical findings from this group are summarized in Table 3 . There were 13 patients in the group ( 7 females, 6 males), with a median age of 60 years, (range, 42-84 years). Lymph node involvement was detected in 10 patients at diagnosis, involving peripheral lymph node in six and being detected only in chest and abdominal CT scans in four cases. Eight cases exhibited extranodal infiltration, localized in the respiratory tract (lung, pleura) in five cases, the skin in three cases and liver in one case. Splenomegaly was observed in nine cases. Bone marrow infiltration was present in 11 patients, while peripheral blood involvement was demonstrated in four cases.

Marginal zone lymphoma patient no. 12 was initially diagnosed with splenic marginal zone lymphoma with bone marrow and peripheral blood infiltration by a small B-cell lymphoma with splenomegaly. However, the patient experienced several relapses with lung, lymph node and parotid involvement, hence we considered her to be following a clinical course atypical for splenic marginal zone lymphoma and so included her in this group of marginal zone lymphoma-not otherwise specified.

Cryoglobulinemia was detected in five cases, and a monoclonal paraprotein was found in two cases. Seven patients were alive after a follow-up of 19129 months following the diagnosis of lymphoproliferative disorders. Five patients died 2, 6, 10, 11 and 181 months, respectively, after diagnosis of lymphoproliferative disorders, the cause of death being related to the lymphoma in only one of them.

Remarkably, marginal zone lymphoma case 7 was diagnosed with only skin involvement, but after relapses with skin, gastric and lymph node involvement, the patient developed a large B-cell lymphoma with gastric infiltration and finally died because of the tumor.

Pathological features. Molecular and light-chain restriction data are presented in Table 2. Marginal zone lymphoma was diagnosed in two lymph node, three lung, two skin and one pleural biopsies. In the other six cases, the diagnosis of marginal zone lymphoma was concluded after taking into account the evidence of lymphadenopathy and/or lung involvement by image techniques with a bone marrow B-cell infiltration with morphological, phenotypic and molecular findings consistent with marginal zone lymphoma. A peripheral lymph node biopsy removed from one case had a conserved architecture but PCR detected a monoclonal IgH rearrangement. The presence of mediastinal and abdominal lymph node involvement (detected by image techniques) with bone marrow infiltration in this case led to a diagnosis of marginal zone lymphoma.

The phenotype in all the cases excluded other small B-cell lymphomas, such as mantle cell lymphoma, follicular lymphoma or chronic lymphocytic leukemia, because of the lack of cyclin D1, BCL6 and 

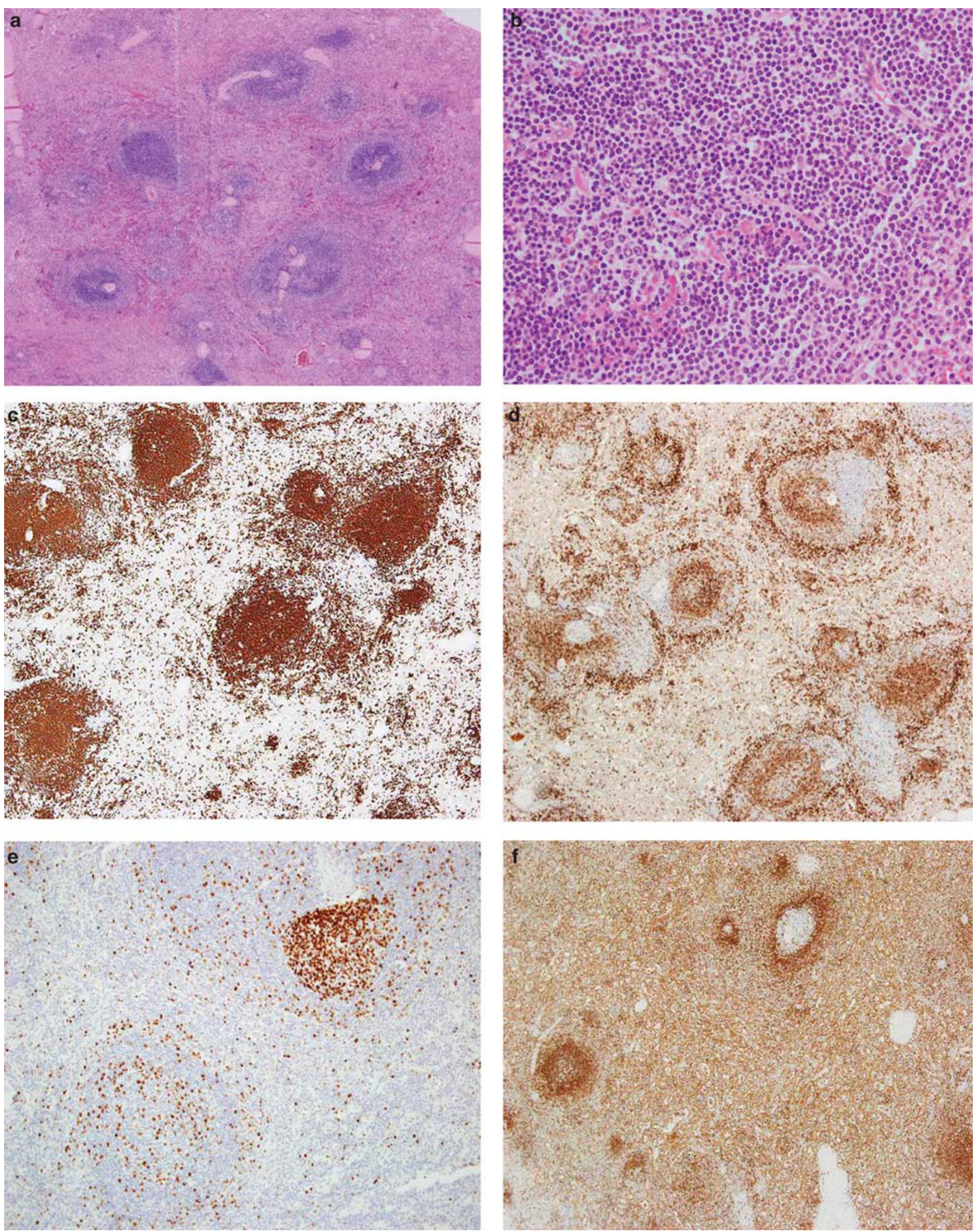

Figure 1 Splenic marginal zone lymphoma case: (a, b) Micronodular pattern with marginal zone differentiation. Immunostaining of (c) CD20 and (d) IgD reveals slight red pulp infiltration. (e) Ki67 and (f) BCL2 showed a reactive germinal center mixed with a germinal center replaced by tumoral cells. 
Table 3 Marginal zone lymphoma: clinical findings

\begin{tabular}{|c|c|c|c|c|c|c|c|c|}
\hline Case & $\begin{array}{l}\text { Age/ } \\
\text { gender }\end{array}$ & Localization & CryogG & $\begin{array}{l}H B \\
g / d l\end{array}$ & $\begin{array}{c}\text { Platelets } \\
\quad / \mu \mathrm{l}\end{array}$ & 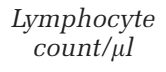 & Treatment & $\begin{array}{l}\text { Follow-up } \\
\text { (months) }\end{array}$ \\
\hline MZL1 & $48 / \mathrm{F}$ & $\begin{array}{l}\text { LN (generalized), lung, BM, PB, } \\
\text { splenomegaly }\end{array}$ & ND & 15 & 125000 & 1800 & $\begin{array}{l}\text { RBV } \\
\text { chemotherapy }\end{array}$ & $\begin{array}{l}\text { Relapse LN } \\
\text { Alive (129) }\end{array}$ \\
\hline MZL2 & $62 / F$ & LN (generalized), BM & + & 9.9 & 66000 & ND & $\begin{array}{l}\text { Chemotherapy } \\
+ \text { BMT }\end{array}$ & $\begin{array}{l}\text { Relapse LN } \\
\text { Alive (104) }\end{array}$ \\
\hline MZL3 & $73 / \mathrm{F}$ & $\begin{array}{l}\text { LN (abdominal, mediastinal), lung, } \\
\text { splenomegaly }\end{array}$ & ND & 14.1 & 173000 & 2700 & Chemotherapy & $\begin{array}{l}\text { Relapse lung } \\
\text { Alive (60) }\end{array}$ \\
\hline MZL4 & $84 / F$ & $\begin{array}{l}\text { LN (retroperitoneal, mediastinal), lung } \\
\text { BM, splenomegaly }\end{array}$ & + & 9.9 & 251000 & 1400 & No & Dead (6), renal failure \\
\hline MZL5 & $74 / \mathrm{M}$ & $\begin{array}{l}\text { LN (retroperitoneal, celiac), pleura, BM, } \\
\text { splenomegaly }\end{array}$ & - & 9.9 & 225000 & 3300 & Chemotherapy & Dead (2) \\
\hline MZL6 & $50 / \mathrm{M}$ & LN (retroperitoneal), BM, PB & + & 16.1 & 222000 & 4600 & ND & ND \\
\hline MZL7 & $47 / F$ & Skin & - & 14.6 & 154000 & 500 & $\begin{array}{l}\text { RBV }+ \text { IF } \\
\text { Chemotherapy }\end{array}$ & $\begin{array}{l}\text { Relapse skin, gastric, } \\
\text { LN, LBCL } \\
\text { Dead (181) }\end{array}$ \\
\hline MZL8 & $42 / \mathrm{M}$ & Skin, splenomegaly, BM & + & 8.7 & 322000 & 1400 & $\mathrm{RBV}+\mathrm{IF}$ & Alive (57) \\
\hline MZL9 & $76 / \mathrm{M}$ & $\begin{array}{l}\text { LN (generalized), lung, BM, liver, } \\
\text { splenomegaly, PB }\end{array}$ & ND & 13.8 & 164000 & 67000 & Chemotherapy & Dead (11) \\
\hline MZL10 & $51 / \mathrm{M}$ & LN (generalized) BM & ND & 17.5 & 268000 & 2800 & Chemotherapy & Alive (20) \\
\hline MZL11 & $59 / \mathrm{F}$ & LN (generalized), skin, BM, splenomegaly & - & 11.6 & 187000 & 660 & RBV & Alive (19) \\
\hline MZL12 & $58 / \mathrm{F}$ & $\mathrm{BM}$, splenomegaly & - & 11.6 & 147000 & 10700 & Chemotherapy & $\begin{array}{l}\text { Relapse parotid, lung, } \\
\text { LN } \\
\text { Alive (100) }\end{array}$ \\
\hline MZL13 & $62 / \mathrm{M}$ & $\begin{array}{l}\text { BM, PB, LN (peripheral, retroperitoneal), } \\
\text { splenomegaly }\end{array}$ & ND & 11.9 & 87000 & 1028 & Chemotherapy & Dead (10) \\
\hline
\end{tabular}

Abbreviations: BM, bone marrow; BMT, bone marrow transplantation; CryoG, cryoglobulinemia; HB hemoglobin; IF, interferon; LN, lymph node; ND, No data; PB, peripheral blood; RBV, Ribavirin.

CD5 and CD23 expression. All the 11 cases tested were p53-negative.

A bone marrow biopsy was evaluated in all the cases. All but two were infiltrated by small B-cells; eight cases had an intertrabecular pattern, two had an interstitial pattern and one had a mixed intertrabecular, interstitial and intrasinusoidal pattern.

Flow cytometry data were available from five cases. Notably, the B-cell infiltrate was CD5 + in two of these, one of which had an additional CD5monoclonal population. Marginal zone lymphoma case 9 had a high level of lymphocytosis but the CD5 - , CD23 - , CD43 - phenotype with strong Ig expression precluded a diagnosis of chronic lymphocytic leukemia.

Marginal zone lymphoma case 7 evolved to diffuse large B-cell lymphoma, as demonstrated in a gastric biopsy.

\section{Follicular Lymphoma}

Clinical findings. This group included eight patients ( 7 females, 1 male), with a median age of 56 years (range, $39-80$ years). Six patients presented clinically with lymph node involvement, one with lymph node and skin infiltration and another one with skin and bone marrow involvement. Bone marrow involvement was found in four out of seven patients. Five patients received chemotherapy at the time of lymphoma diagnosis. Four of them were alive after a follow-up of 14, 29, 38 and 49 months, respectively. Two patients died 25 and 27 months, respectively, after diagnosis. We do not have followup information about two patients.
Pathological features. Molecular and light-chain restriction data are shown in Table 2. The lymph node biopsy was evaluable in seven patients. In all the cases, the infiltrate had a nodular pattern, and the cytology consisted of centrocyte and centroblast cells, which were low grade in seven cases and high grade in one. Tumors were BCL2 + in four of the six cases, and p53 + in three of the six cases.

Two cutaneous biopsies showed lymphoid proliferation with a nodular pattern involving dermis and subcutaneous tissue. In both the cases, the phenotype of tumoral cells was CD20 +, BCL2 +, BCL6+, consistent with disseminated follicular lymphoma.

The bone marrow pattern of infiltration was peritrabecular in all the cases with bone marrow infiltration (including both cases with skin involvement) except one, which featured intertrabecular follicles.

\section{Large B-cell Lymphoma}

Seven patients were diagnosed with large B-cell lymphoma ( 2 females, 5 males). The median age was 67 years (range, 41-91 years). Lymph node involvement was present in four cases, spleen in two cases and liver in one. Splenomegaly was observed in four cases. Bone marrow biopsy was examined in four cases, with no large B-cell infiltration in any of them. Two patients were also diagnosed with hepatocarcinoma. Three patients were alive 6, 21 and 106 months, respectively, after diagnosis. The other four patients received only symptomatic treatment because of their poor performance status. 
Pathological findings. Molecular and light-chain restriction data are shown in Table 2 . All but one case showed diffuse proliferation of large B cells. Of these, the phenotype was CD20 + (6/6 cases), BCL6 + (6/6), CD10 + (1/2), BCL2 + (3/6), with p53 overexpression in two of the five cases. Only a cytological examination was available in the seventh case. It is of particular interest that one of the cases with spleen involvement by large B-cell lymphoma featured a monoclonal B-cell population in the peripheral blood and bone marrow and splenic-associated findings consistent with splenic marginal zone lymphoma. A small B-cell component was not observed in the other large B-cell lymphoma involving the spleen.

\section{Other Diseases}

Lymphoplasmacytic lymphoma was found in two patients, both with bone marrow involvement and, in one of them, mediastinal and abdominal lymphadenopathy. None of them showed splenomegaly. Both patients were alive after a follow-up of 63 and 53 months, respectively. Bone marrow was available for both cases, the examination revealing a nodular and interstitial infiltration by a polymorphic population of plasma cells, lymphocytes and lymphoplasmacytoid cells.

Two further cases presented bone marrow infiltration by plasma cells and monoclonal serum protein without splenomegaly or lymphadenopathy. These cases fulfilled the criteria for a diagnosis of multiple myeloma. Both received only a conservative treatment because they were 78- and 79-years old, respectively, and had a poor performance status. Another patient showed a monoclonal serum protein of $2.4 \mathrm{~g} / \mathrm{dl}$ with a monoclonal plasma cell population in bone marrow of $2 \%$, so the diagnosis of this patient was consistent with monoclonal gammopathy of undetermined significance.

Two patients diagnosed with chronic leukemia lymphatic leukemia displayed peripheral lymph node involvement and splenomegaly. They presented the highest lymphocyte counts in the series, 33725 and $11700 / \mu$ l, respectively, with a classic CD5 +, CD23 + phenotype. They died 10 and 12 months, respectively, after diagnosis.

One patient was diagnosed with Burkitt lymphoma with lymph node and liver involvement. He was alive 86 months after diagnosis. The final patient presented with splenomegaly, abdominal lymph nodes and a bone marrow biopsy showing infiltration by a small B-cell proliferation with an elevated level of blast cells. In spite of treatment with chemotherapy, he died from a tumor 6 months after diagnosis.

\section{HCV-Associated Monoclonal B-cell Lymphocytosis}

This group included cases with B-cell clonal expansion demonstrated by flow cytometry, immuno- histochemistry and/or PCR IgH rearrangement in bone marrow and/or peripheral blood samples, without clinical or histological evidence of lymphoma infiltration. Presence of splenomegaly was not considered to be evidence of malignant lymphoma, as it may be related to the active infection by HCV.

Clinical findings. Eleven patients were included in this group (four females, seven males) with a median age of 62 years (range, 45-84 years). Three patients had cirrhosis, and splenomegaly was detected in eight patients. Small abdominal lymph nodes were detected by CT examination in three patients, one of which could be attributed to metastasis by colorectal carcinoma. Cryoglobulinemia was demonstrated in three patients, and two presented with autoimmune hemolytic anemia. The mean leukocyte count was 6572/ $\mu$ l (range, 2.7-11.8) and the mean lymphocyte count was 3037/ $\mu$ l (range, 800-6386). Although the two patients had a lymphocyte count $>5000 / \mu \mathrm{l}$, the $\mathrm{CD} 19$ + population in peripheral blood was 22 and $12 \%$ of the leukocyte count, respectively. Four patients received chemotherapy. Splenectomy was performed for therapeutic and diagnosis purposes in one patient. All patients but one, who was suffering from a colorectal carcinoma, were alive after a follow-up between 12 and 57 months.

Pathological findings. Molecular and light-chain restriction data are shown in Table 2. Bone marrow samples were available for all the cases. Intertrabecular nodules were observed in seven cases, intrasinusoidal involvement was detected in five cases and solely interstitial infiltration was demonstrated in one case (Figure 2). Flow cytometry analysis was possible for nine cases, the degree of bone marrow infiltration by lymphoid cell varying between 5 and $44 \%$ (median, 20\%). Only two of the nine cases were CD5 +, both of which were CD23 - . There was also a small population of plasma cells (range, 4-9\%).

The spleen was analyzed in one case, which had a small lymphoid infiltration in the red pulp CD20 +, IGD +, whereas the white pulp presented a reactive germinal center without follicular replacement. The bone marrow of this patient showed interstitial B-cell infiltration. It is of particular interest that the patient with splenomegaly, small abdominal lymph nodes, bone marrow and peripheral blood involvement in B-cell expansion with marginal zone phenotype had splenic findings that were not consistent with the characteristics of classical splenic marginal zone lymphoma (Figure 3).

\section{Tissue-based Monoclonal B-cell and Plasma Cell Proliferations of Uncertain Type}

An enlargement of hepatic hilar lymph node was detected in one patient by a CT scan during the clinical evaluation of HCV infection, so liver and lymph node biopsies were done. The histological 

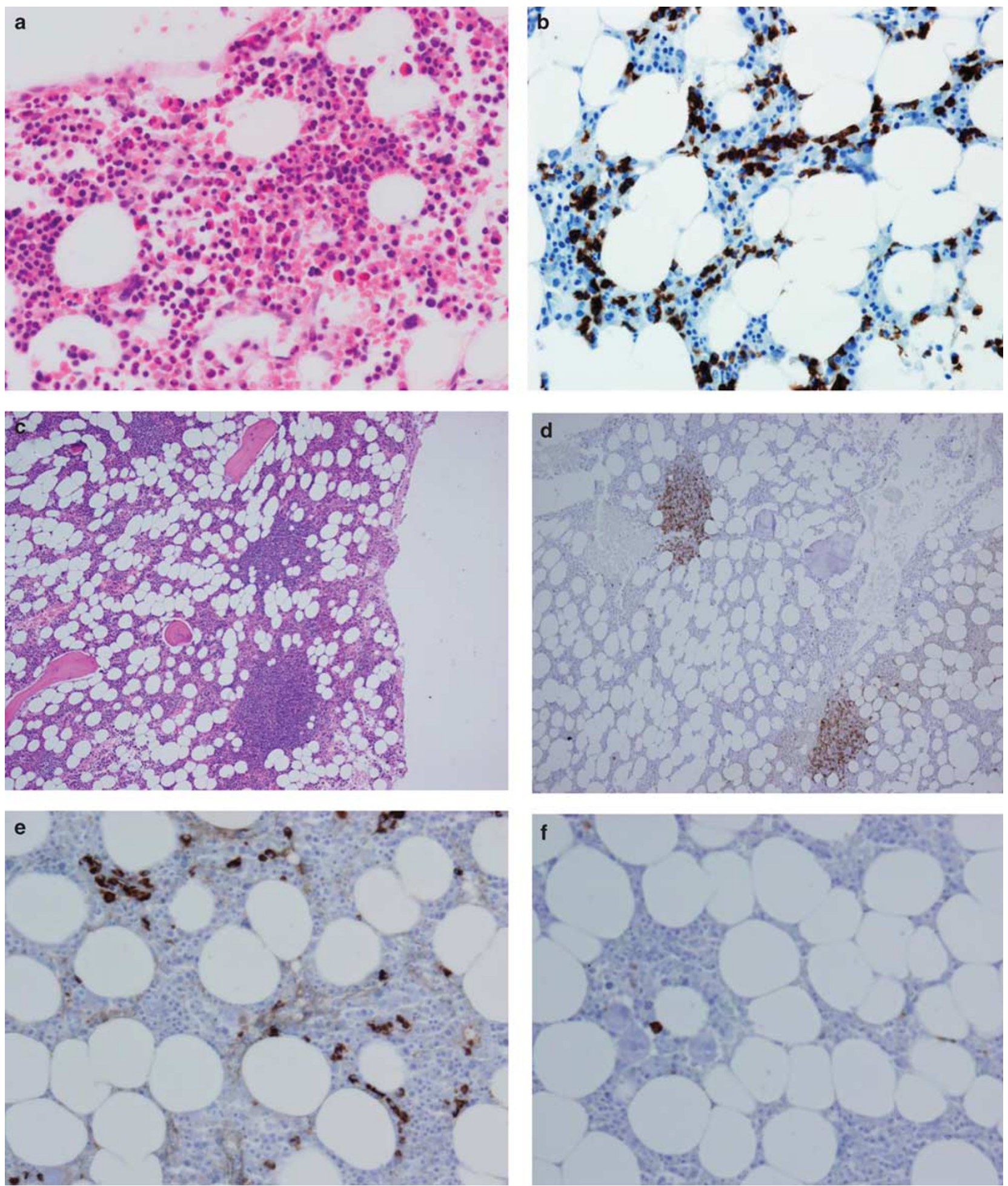

Figure 2 HCV-associated monoclonal B-cell lymphocytosis. Bone marrow pattern: (a) Intrasinusoidal pattern highlighted by (b) CD20. (c) Intertrabecular lymphoid nodule (d) CD20 + with plasma cell infiltrate (e) kappa + and (f) lambda - .

examination of the lymph node had a conserved architecture, with reactive germinal centers. Immunohistochemical analysis showed a CD20 + , CD5 + , kappa population in the marginal zone area (Figure 4). Additional confirmation of the monoclonal infiltrate was obtained after PCR IgH study.
The liver biopsy showed a portal infiltrate of CD20 + , CD5 + lymphocyte with the same rearrangement as that of the lymph node biopsy. The patient received no treatment and was alive without evidence of lymphoproliferative disorder 3 years after her initial diagnosis. 

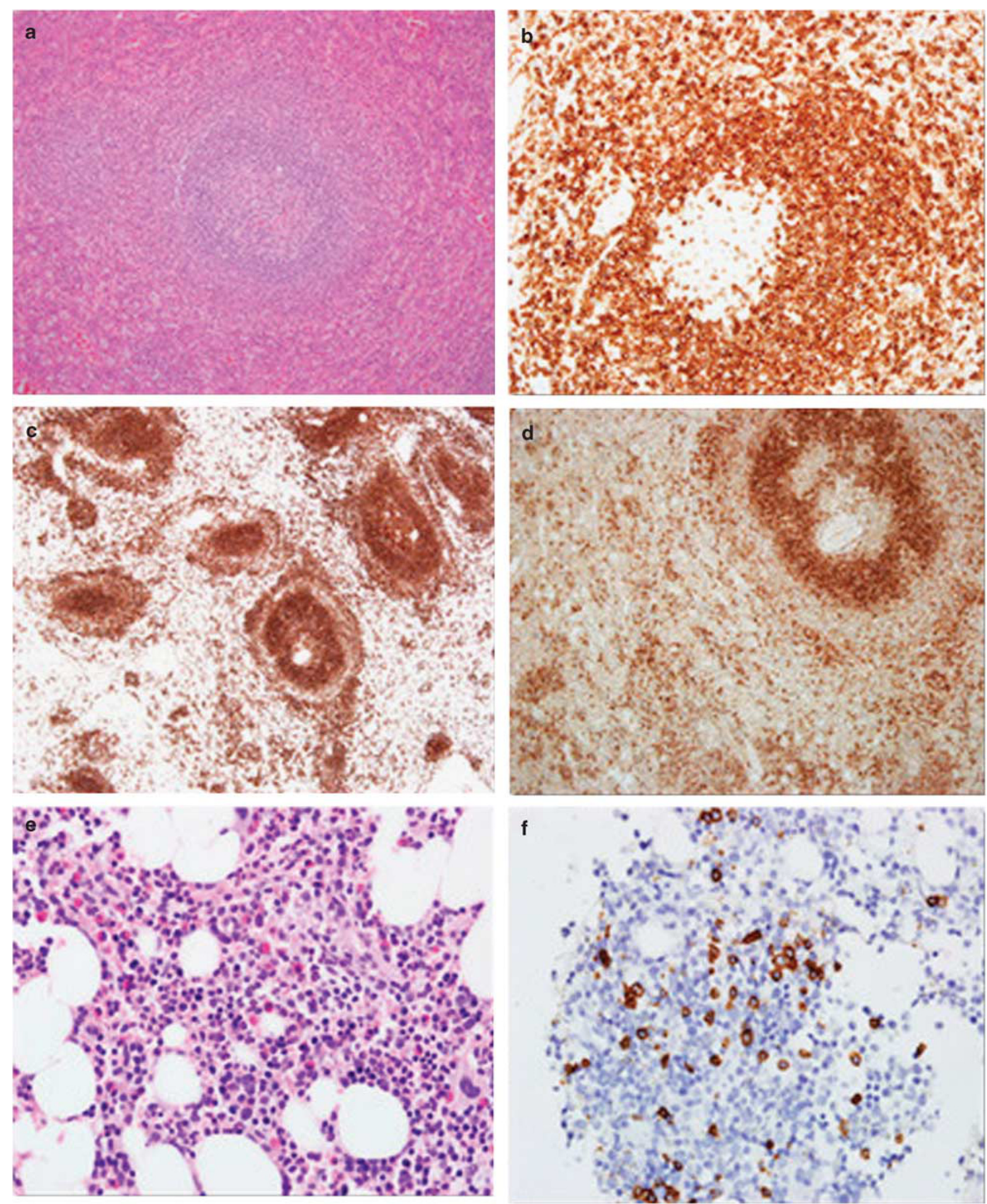

Figure 3 HCV-associated monoclonal B-cell lymphocytosis. Spleen morphology: (a) Splenectomy specimen with reactive germinal center (b) BCL2 - with (c) CD20 + and (d) IgD + lymphoid infiltrate in the red pulp. (e) Bone marrow biopsy with scant interstitial (f) CD20 + infiltrate.

In the second patient, a nasal papilloma was removed 13 years after the initial diagnosis of HCV. Remarkably, one of the examined fragments included focal bone marrow showing a dense infiltrate of small B cells CD20 +, BCL2 +, BCL6 - , CD5 - , CD23 - with kappa light-chain restriction. 
The third case of this group was a patient diagnosed with cryoglobulinemia and VHC who finally died from renal failure. The spleen was normal sized, with infarcted areas and a monotypic infiltrate of plasma cells in the red pulp.

\section{Analysis of BCL2 and IgHV Genes Rearrangements}

Somatic mutations (varying from 88.9 to $96.0 \%$ ) in the IgVH genes were detected in all the five clonal rearrangements that could be evaluated. VH3-23 was used in two cases, while VH3-15, VH3-30 and VH169 were used in one case each.

All but one case tested negative for a BCL2 rearrangement (two cases by FISH, 15 cases by PCR). The only case with a BCL2 rearrangement was identified by FISH in a lymph node biopsy diagnosed with follicular lymphoma.

\section{Discussion}

We have reviewed the clinicopathological features of monoclonal B-cell lymphoproliferative lesions associated with HCV infection. The most common lymphoma types diagnosed were marginal zone lymphoma, diffuse large B-cell lymphoma and follicular lymphoma. These data are consistent with those reported by a previous study ${ }^{19}$ but differ from those of another report. ${ }^{5}$

We noted a spectrum of clinicopathological disorders, varying from patients with distinct clinical or histological evidence of lymphoma involving lymph node, spleen and/or extranodal tissues to cases in which monoclonal B-cell lymphocytosis was detected as the presence of a monoclonal B-cell population in peripheral blood, bone marrow and/or other tissues. There was a subset of cases with borderline, intermediate features. Examples of this intermediate histology and/or behavior are marginal zone lymphoma case 12, in which an initial diagnosis of splenic marginal zone lymphoma was followed by a visceral and systemic infiltration, and marginal zone lymphoma case 7 , in which, after an initial diagnosis of cutaneous marginal zone lymphoma, MALT-type, an extracutaneous infiltration was seen, with visceral and lymph node infiltration, which finally led to the death of the patient. We have given the name 'marginal zone lymphoma not otherwise specified' to this subset of cases with features that cannot be classified by the standard WHO categories of splenic marginal zone lymphoma, marginal zone lymphoma-MALT type or nodal marginal zone lymphoma.

An interesting finding of our review is the presence of a substantial number of cases with monoclonal B cells in peripheral blood, bone marrow or other tissues, in the absence of definite clinical or histological evidence of neoplastic infiltration. Criteria for monoclonal B lymphocytosis diagnosis have been clearly established in peripheral blood samples.
However, no clear cutoff data were available to identify monoclonal B lymphocytosis involving the bone marrow or extramedullary tissue, although a value of $>30 \%$ of nucleated cells in the bone marrow aspirate has been suggested. ${ }^{20}$ Recently, one study has proposed lymph node size to be a criterion for separating small lymphocytic lymphoma/chronic lymphocytic leukemia from monoclonal B lymphocytosis in lymph nodes, ${ }^{21}$ but this is not applicable to the cases considered here. This observation confirms and expands previous descriptions of clonal B-cell population in the blood of HCV-infected persons, as well as clonal B-cell infiltrates in the bone marrow and liver biopsies of patients with HCV infection, associated or not with cryoglobulinemia. ${ }^{22-26}$ These infiltrates were shown to remain unmodified during a long follow-up in most cases but can be followed up as overt lymphoma in about $10 \%$ of them. The term 'monotypic lymphoproliferative disorder of undetermined significance" ${ }^{\text {" has }}$ been proposed for these cases. Moreover, it has been demonstrated that lymphomas developed in patients with these peripheral blood and/or bone marrow monoclonal populations may be clonally unrelated. Consistent with this, the marginal zone lymphoma case 11 diagnosed as being at clinical stage IV with skin, lymph node and bone marrow involvement had different $\mathrm{IgVH}$ clones at separate locations. Additionally, bone marrow clonal B-cell expansion in patients with HCV infection has not been statistically associated with the presence of overt lymphoma. ${ }^{27}$

Remarkably, in our series, splenomegaly was detected by CT examination in $58 \%$ of patients, while peripheral blood and bone marrow monoclonal B-cell infiltration were detected in 33 and $84 \%$ of cases, respectively.

This review also highlights the difficulties of differentiating between splenic marginal zone lymphoma and monoclonal B lymphocytosis in HCV patients, in which splenomegaly can be attributed to the HCV infection. This is particularly pertinent when only bone marrow sections are available for establishing the difference, as also shown by de Vita et al. ${ }^{28}$

Splenic marginal zone lymphoma features in $\mathrm{HCV}$ patients in this series are the same as those in HCV-negative cases, except for a lower degree of spleen tissue infiltration. CGH array studies have also highlighted the lack of any difference in DNA copy number changes in splenic marginal zone lymphoma, when comparing HCV-positive and HCV-negative samples. ${ }^{29}$

HCV-positive cases have an increased incidence of lymphoplasmacytic lymphomas, often in association with mixed cryoglobulinemia. ${ }^{30}$ Precise criteria for differentiating lymphoplasmacytic lymphomas and monoclonal B-lymphocytosis are still lacking, however.

In addition to bone marrow and peripheral blood samples containing monoclonal B lymphocytosis, we found a monoclonal B-cell population in three 

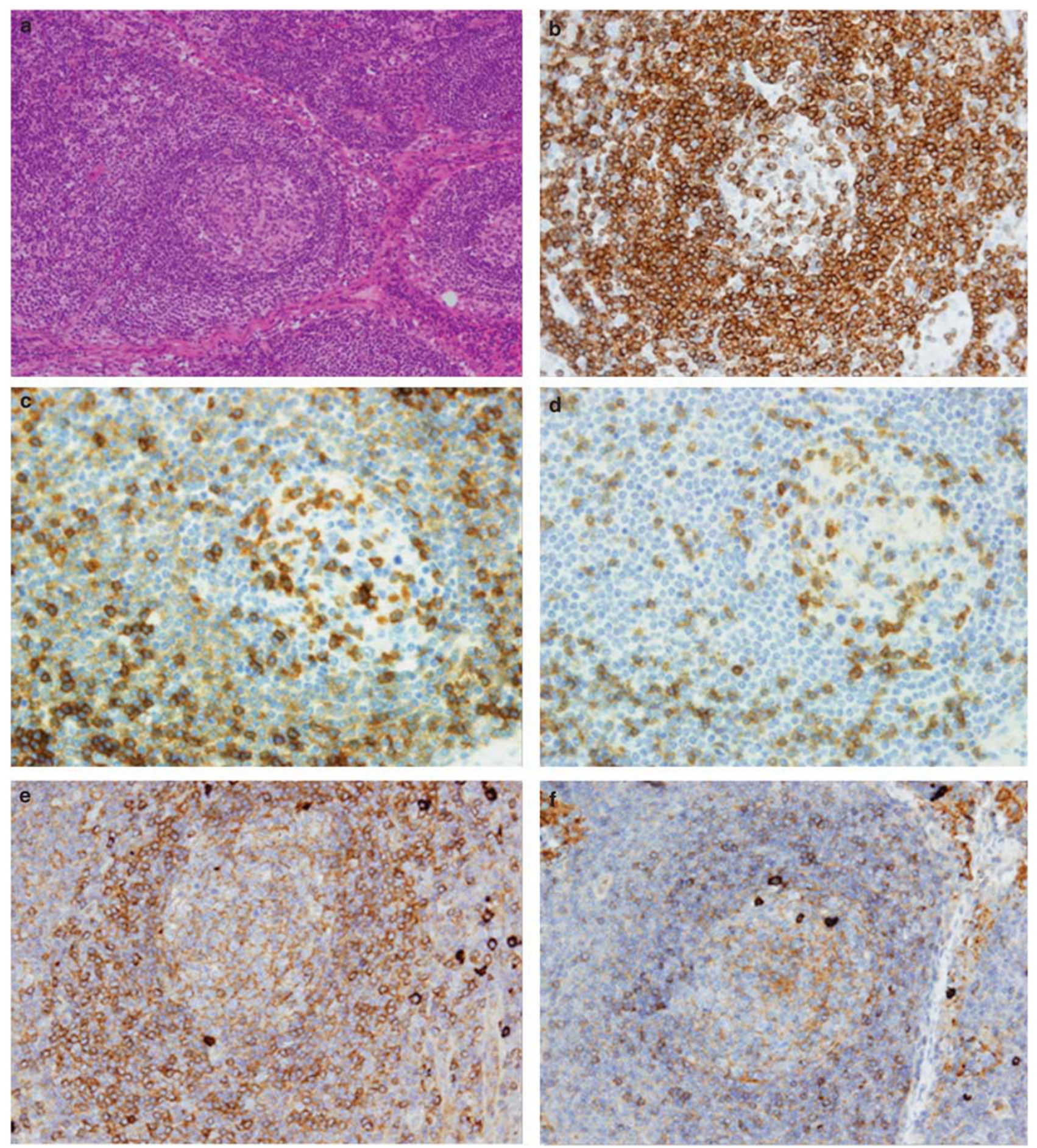

Figure 4 Tissue-based monoclonal B-cell and plasma cell proliferations of uncertain type. Lymph node: (a) Reactive germinal centers (b) BCL2 - with (c) CD5 + , (d) CD3 - (e) kappa + and (f) lambda - cell populations in the marginal zone.

cases (in lymph node, nasal polyp and spleen), without any clinical evidence of lymphoma. This finding can be considered an incidental observation of monoclonal B-cell expansion with a very low probability of developing systemic disease, as reported by Rawstron. ${ }^{20}$

Although $>80 \%$ of all monoclonal B lymphocytosis expressed CD5 antigen in healthy HCV- negative individuals, ${ }^{12}$ monoclonal B lymphocytosis cases were CD5 - in our series. Interestingly, two of the marginal zone lymphomas described here expressed CD5.

Two of the six follicular lymphoma cases showed cutaneous involvement either at diagnosis or during the course of the disease. Although a possible diagnosis of marginal zone lymphoma was 
considered in these cases, the presence of BCL6 expression combined with bone marrow involvement with a paratrabecular pattern support the diagnosis of follicular lymphoma.

Two of the seven diffuse large B-cell lymphomas reviewed were restricted to the spleen. One of the cases showing $\mathrm{IgD}$ expression was considered as progression from splenic marginal zone lymphoma, as the examination of splenic parenchyma outside large B-cell lymphoma showed morphological and phenotypic features of splenic marginal zone lymphoma, as well as bone marrow and peripheral blood infiltration by a monoclonal $\mathrm{B}$ population with a phenotype consistent with splenic marginal zone lymphoma. In a large series of large B-cell lymphomas, HCV-positive patients had a higher proportion of spleen involvement than HCVnegative patients. ${ }^{31,32}$

Although rearrangement of $B C L 2$ has been found at a higher frequency in the peripheral blood mononuclear cells from patients with chronic HCV infection and mixed cryoglobulinemia, ${ }^{33}$ this molecular alteration was not more common in the lymphoma biopsy specimen from patients with HCV infection than in those who were HCV-negative. ${ }^{34}$ All cases in this study were found to be negative for the BCL2 translocation by FISH or PCR.

On the other hand, HCV increases the frequency of the TP53 gene mutation. ${ }^{35}$ We observed overexpression of p53 in two of the five follicular lymphoma and three of the five large B-cell lymphoma cases, respectively.

In summary, the study identifies two major areas in which diagnosis of HCV-positive patients requires close integration with other clinical and molecular data: disseminated marginal zone lymphoma lacking splenic marginal zone lymphoma features and monoclonal B-cell lymphocytosis in bone marrow, peripheral blood or other tissues.

\section{Acknowledgements}

We thank $\mathrm{P}$ Dominguez, $\mathrm{R}$ Córdoba (Madrid), F García-Bragado (Pamplona), MJ Artiga (CNIO Tumour Bank) and R Rodríguez (HVS Tumor Bank, BioB-HVS) for kindly providing some of the cases included in this series, and C Granda and G PerezDíaz (Hospital Virgen de la Salud, Toledo) for their technical assistance. This study was supported by Grants from the Ministerio de Ciencia e Innovación (RETICS, FIS PI081666, INT10/080, SAF200803871), the Servicio de Salud de Castilla la Mancha (FISCAM PI2008/31) and the Asociación Española Contra el Cancer (AECC).

\section{Disclosure/conflict of interest}

The authors declare no conflict of interest.

\section{References}

1 Ferri C, Zignego AL, Pileri SA. Cryoglobulins. J Clin Pathol 2002;55:4-13.

2 Pozzato G, Mazzaro C, Crovatto M, et al. Low-grade malignant lymphoma, hepatitis $\mathrm{C}$ virus infection, and mixed cryoglobulinemia. Blood 1994;84:3047-3053.

3 de Sanjose S, Benavente Y, Vajdic CM, et al. Hepatitis $\mathrm{C}$ and non-Hodgkin lymphoma among 4784 cases and 6269 controls from the International Lymphoma Epidemiology Consortium. Clin Gastroenterol Hepatol 2008;6:451-458.

4 Hermine O, Lefrere F, Bronowicki JP, et al. Regression of splenic lymphoma with villous lymphocytes after treatment of hepatitis C virus infection. N Engl J Med 2002;347:89-94.

5 Dal Maso L, Franceschi S. Hepatitis $C$ virus and risk of lymphoma and other lymphoid neoplasms: a metaanalysis of epidemiologic studies. Cancer Epidemiol Biomarkers Prev 2006;15:2078-2085.

6 Duberg AS, Nordstrom M, Torner A, et al. NonHodgkin's lymphoma and other nonhepatic malignancies in Swedish patients with hepatitis C virus infection. Hepatology 2005;41:652-659.

7 de Sanjose S, Nieters A, Goedert JJ, et al. Role of hepatitis $\mathrm{C}$ virus infection in malignant lymphoma in Spain. Int J Cancer 2004;111:81-85.

8 Isaacson PG, Piris MA, Berger F, et al. Splenic B-cell marginal zone lymphoma, In: Swerdlow SH, Campo E, Harris NL, et al. (eds). WHO Classification of Tumours of Haematopoietic and Lymphoid Tissues. IARC Press: Lyon, France; 2008, pp 185-187.

9 Matutes E, Oscier D, Montalban C, et al. Splenic marginal zone lymphoma proposals for a revision of diagnostic, staging and therapeutic criteria. Leukemia 2008;22:487-495.

10 Campo E, Pileri SA, Jaffe ES, et al. Nodal marginal zone lymphoma, In: Swerdlow SH, Campo E, Harris NL, et al. (eds). WHO Classification of Tumours of Haematopoietic and Lymphoid Tissues. IARC Press: Lyon, France; 2008, pp 218-219.

11 Isaacson PG, Chot A, Nakamura S, et al. Extranodal marginal zone lymphoma of mucosa-associated lymphoid tissue (MALT lymphoma)., In: Swerdlow SH, Campo E, Harris NL, et al. (eds). WHO Classification of Tumours of Haematopoietic and Lymphoid Tissues. IARC Press: Lyon, France; 2008, pp 214-217.

12 Fazi C, Dagklis A, Cottini F, et al. Monoclonal B cell lymphocytosis in hepatitis $\mathrm{C}$ virus infected individuals. Cytometry B Clin Cytom 2010;78(Suppl 1): S61-S68.

13 Swerdlow SH, Berger F, Pileri SA, et al. Lymphoplasmacytic lymphoma, In: Swerdlow SH, Campo E, Harris NL, et al. (eds). WHO Classification of Tumours of Haematopoietic and Lymphoid Tissues. IARC Press: Lyon, France; 2008, pp 194-195.

14 Harris NL, Swerdlow SH, Jaffe ES, et al. Follicular lymphoma, In: Swerdlow SH, Campo E, Harris NL, et al. (eds). WHO Classification of Tumours of Haematopoietic and Lymphoid Tissues. IARC Press: Lyon, France; 2008, pp 220-226.

15 Stein H, Warnke RA, Chan WC, et al. Diffuse large B-cell lymphoma, not otherwise specified, In: Swerdlow SH, Campo E, Harris NL, et al. (eds). WHO Classification of Tumours of Haematopoietic and Lymphoid Tissues. IARC Press: Lyon, France; 2008, pp 233-237. 
16 Müller-Hermelink HK, Montserrat E, Catovsky D, et al. Chronic lymphocytic leukaemia/small lymphocytic lymphoma, In: Swerdlow SH, Campo E, Harris NL, et al. (eds). WHO Classification of Tumours of Haematopoietic and Lymphoid Tissues. IARC Press: Lyon, France; 2008, pp 180-182.

17 McKenna RW, Kyle RA, Kuehl WM, et al. Plasma cell neoplasms, In: Swerdlow SH, Campo E, Harris NL, et al. (eds). WHO Classification of Tumours of Haematopoietic and Lymphoid Tissues. IARC Press: Lyon, France; 2008, pp 200-213.

18 van Dongen JJ, Langerak AW, Bruggemann M, et al. Design and standardization of PCR primers and protocols for detection of clonal immunoglobulin and T-cell receptor gene recombinations in suspect lymphoproliferations: report of the BIOMED-2 Concerted Action BMH4-CT98-3936. Leukemia 2003;17: 2257-2317.

19 Luppi M, Longo G, Ferrari MG, et al. Clinicopathological characterization of hepatitis $\mathrm{C}$ virusrelated B-cell non-Hodgkin's lymphomas without symptomatic cryoglobulinemia. Ann Oncol 1998;9: 495-498.

20 Rawstron AC. Occult B-cell lymphoproliferative disorders. Histopathology 2011;58:81-89.

21 Gibson SE, Swerdlow SH, Ferry JA, et al. Reassessment of small lymphocytic lymphoma in the era of monoclonal B-cell lymphocytosis. Haematologica 2011;96: 1144-1152.

22 De Vita S, De ReV, Gasparotto D, et al. Oligoclonal nonneoplastic B cell expansion is the key feature of type II mixed cryoglobulinemia: clinical and molecular findings do not support a bone marrow pathologic diagnosis of indolent B cell lymphoma. Arthritis Rheum 2000;43:94-102.

23 Magalini AR, Facchetti F, Salvi L, et al. Clonality of B-cells in portal lymphoid infiltrates of HCV-infected livers. J Pathol 1998;185:86-90.

24 Racanelli V, Sansonno D, Piccoli C, et al. Molecular characterization of B cell clonal expansions in the liver of chronically hepatitis C virus-infected patients. J Immunol 2001;167:21-29.
25 Franzin F, Efremov DG, Pozzato G, et al. Clonal B-cell expansions in peripheral blood of HCV-infected patients. Br J Haematol 1995;90:548-552.

26 Monteverde A, Sabattini E, Poggi S, et al. Bone marrow findings further support the hypothesis that essential mixed cryoglobulinemia type II is characterized by a monoclonal B-cell proliferation. Leuk Lymphoma 1995;20:119-124.

27 Quartuccio L, Fabris M, Salvin S, et al. Bone marrow B-cell clonal expansion in type II mixed cryoglobulinaemia: association with nephritis. Rheumatology (Oxford) 2007;46:1657-1661.

28 De Vita S, Sacco C, Sansonno D, et al. Characterization of overt B-cell lymphomas in patients with hepatitis C virus infection. Blood 1997;90:776-782.

29 Novara F, Arcaini L, Merli M, et al. High-resolution genome-wide array comparative genomic hybridization in splenic marginal zone B-cell lymphoma. Hum Pathol 2009;40:1628-1637.

30 Silvestri F, Pipan C, Barillari G, et al. Prevalence of hepatitis $\mathrm{C}$ virus infection in patients with lymphoproliferative disorders. Blood 1996;87:4296-4301.

31 Besson C, Canioni D, Lepage E, et al. Characteristics and outcome of diffuse large B-cell lymphoma in hepatitis $\mathrm{C}$ virus-positive patients in LNH 93 and LNH 98 Groupe d'Etude des Lymphomes de l'Adulte programs. J Clin Oncol 2006;24:953-960.

32 Visco C, Arcaini L, Brusamolino E, et al. Distinctive natural history in hepatitis $\mathrm{C}$ virus positive diffuse large B-cell lymphoma: analysis of 156 patients from northern Italy. Ann Oncol 2006;17:1434-1440.

33 Zignego AL, Ferri C, Giannelli F, et al. Prevalence of bcl-2 rearrangement in patients with hepatitis $C$ virusrelated mixed cryoglobulinemia with or without B-cell lymphomas. Ann Intern Med 2002;137:571-580.

34 Libra M, De ReV, De Vita S, et al. Low frequency of bcl2 rearrangement in HCV-associated non-Hodgkin's lymphoma tissue. Leukemia 2003;17:1433-1436.

35 Machida K, Cheng KT, Sung VM, et al. Hepatitis C virus induces a mutator phenotype: enhanced mutations of immunoglobulin and protooncogenes. Proc Natl Acad Sci USA 2004;101:4262-4267. 